Erzincan Üniversitesi

Fen Bilimleri Enstitüsü Dergisi

2020, 13(3), 1016-1024

e-ISSN: 2149-4584

Araştırma Makalesi
Erzincan University Journal of Science and Technology

2020, 13(3), 1016-1024

DOI: $10.18185 /$ erzifbed.704421

\title{
First Description of Larva of Trombidium rimosum C. L. Koch, 1837 (Acari: Trombidiidae) From Turkey
}

\author{
İbrahim KARAKURT ${ }^{1 *}$, Sevgi SEVSAY ${ }^{2}$ (D) \\ ${ }^{1}$ Department of Home Care, Vocational School of Health Services, Erzincan Binali Yıldırım University, \\ Erzincan, Turkey. \\ ${ }^{2}$ Department of Biology, Faculty of Arts and Sciences, Erzincan Binali Y1ldırım University, Erzincan, Turkey. \\ Geliş / Received: 16/03/2020, Kabul / Accepted: 15/09/2020
}

\begin{abstract}
Trombidium rimosum Koch, 1837 which shows distribution in Europe, has been known only to postlarval forms to date. In this study, for the first time, larvae of T. rimosum are described and illustrated from Turkey. All larvae were obtained by experimental rearing from field-collected females. Also, an abnormality was noted for the larvae of this species.
\end{abstract}

Keywords: Trombidium, larva, first description, abnormality

\section{Trombidium rimosum C. L. Koch, 1837 (Acari: Trombidiidae) larvalarının ilk kez Türkiye'den tanımlanması}

\section{Öz}

Avrupa'da yayılım gösteren, Trombidium rimosum Koch, 1837 türü şimdiye kadar sadece ergin formlarından bilinmektedir. Bu çalışmada, ilk kez, T. rimosum larvaları Türkiye'den tanımlanmış ve çizimleri verilmiştir. Tüm larvalar, araziden toplanan dişi bireylerden, elde edilmiştir. Ayrıca bu türün larvalarına ait bir morfolojik farklılık belirlenmiştir.

Anahtar Kelimeler: Trombidium, larva, ilk tanımlama, anormallik

*Corresponding Author: ibrahim.karakurt@erzincan.edu.tr, 


\section{Introduction}

Trombidium Fabricius, 1775 is represented by 36 species (Sevsay et al., 2020). Twelve of them are known from both postlarval and larval stage, of which 12 larvae and 12 from active postlarval forms (Mąkol and Wohltmann, 2012; Mąkol and Wohltmann, 2013; Saboori et al., 2017; Sevsay et al., 2020). However, only seven species of Trombidium were reported by Sevsay et al. (2016), Sevsay (2017) and Sevsay et al. (2020) from Turkey. Among them, three species (Trombidium brevimanum (Berlese, 1910), Trombidium mediterraneum (Berlese, 1910) and Trombidium rimosum Koch, 1837) are known based on their postlarval forms. In contrast, Trombidium demirsoyi Sevsay and Buğa, 2020 only known as larvae, three species (Trombidium geniculatum (Feider, 1955), Trombidium holosericeum (Linnaeus, 1758) and Trombidium latum Koch, 1837) known as both postlarval and larvae. The neotype designation of $T$. rimosum was provided based on adult form by Mąkol (2005), and this species known only based on adults, so far. This study contains first detailed descriptions of the larvae of $T$. rimosum based on individuals obtained from fieldcollected females in laboratory conditions.

\section{Material and methods}

Active postlarval forms were collected directly from Bayburt province $\left(40^{\circ} 26^{\prime} \mathrm{N}\right.$ $40^{\circ} 07^{\prime} \mathrm{E} 2220 \mathrm{~m}$ a.s.1., the soil surface, on a humid litter, 01.05.2013), Turkey. Ovigerous females collected in the field were placed in glass vials $(25 \times 35 \mathrm{~mm})$ that contained a mixture of charcoal and plaster (9:1). The females were transferred to $70 \%$ ethyl alcohol after oviposition. Larvae were obtained from the eggs laid by the females. The eggs were provided $2-3$ $\mathrm{ml}$ of distilled water once every three days, added to the substratum to maintain humidity. The glass vials were kept at room temperature $\left(22-25{ }^{\circ} \mathrm{C}\right)$. Specimens $(1$ q, 15 larvae) were mounted on slides using Hoyer's medium as suggested by Walter and Krantz (2009). Examined materials were preserved in $70 \%$ ethyl alcohol. The morphological terminology and abbreviations follow Mąkol (2005). For measurements, photographs and drawings an Olympus BX63 microscope was used. All measurements are given in micrometers ( $\mu \mathrm{m})$.

\section{Results}

Family: Trombidiidae Leach, 1815

Genus: Trombidium Fabricus, 1775

\section{Trombidium rimosum Koch, 1837}

Diagnosis: Adults (Figures $1 \mathrm{~A}-\mathrm{D}$ ) (For more information see Mąkol, 2005). Crista metopica with rounded sensillary area and relatively wide posterior process. Dorsal setae distinctly widened in the distal part, setal stems almost parallelsided, densely covered with setules. $p D S$ I with asymmetrical (hammer-like) termination accommodating a big air chamber. $p D S$ II slightly asymmetrical with termination producing several tubercles (Mąkol, 2005). Genital opening with three pairs of genital acetabula. Tarsus I elongate, tibia I shorter than tarsus I.

Description: Adults (see Mąkol, 2005). 


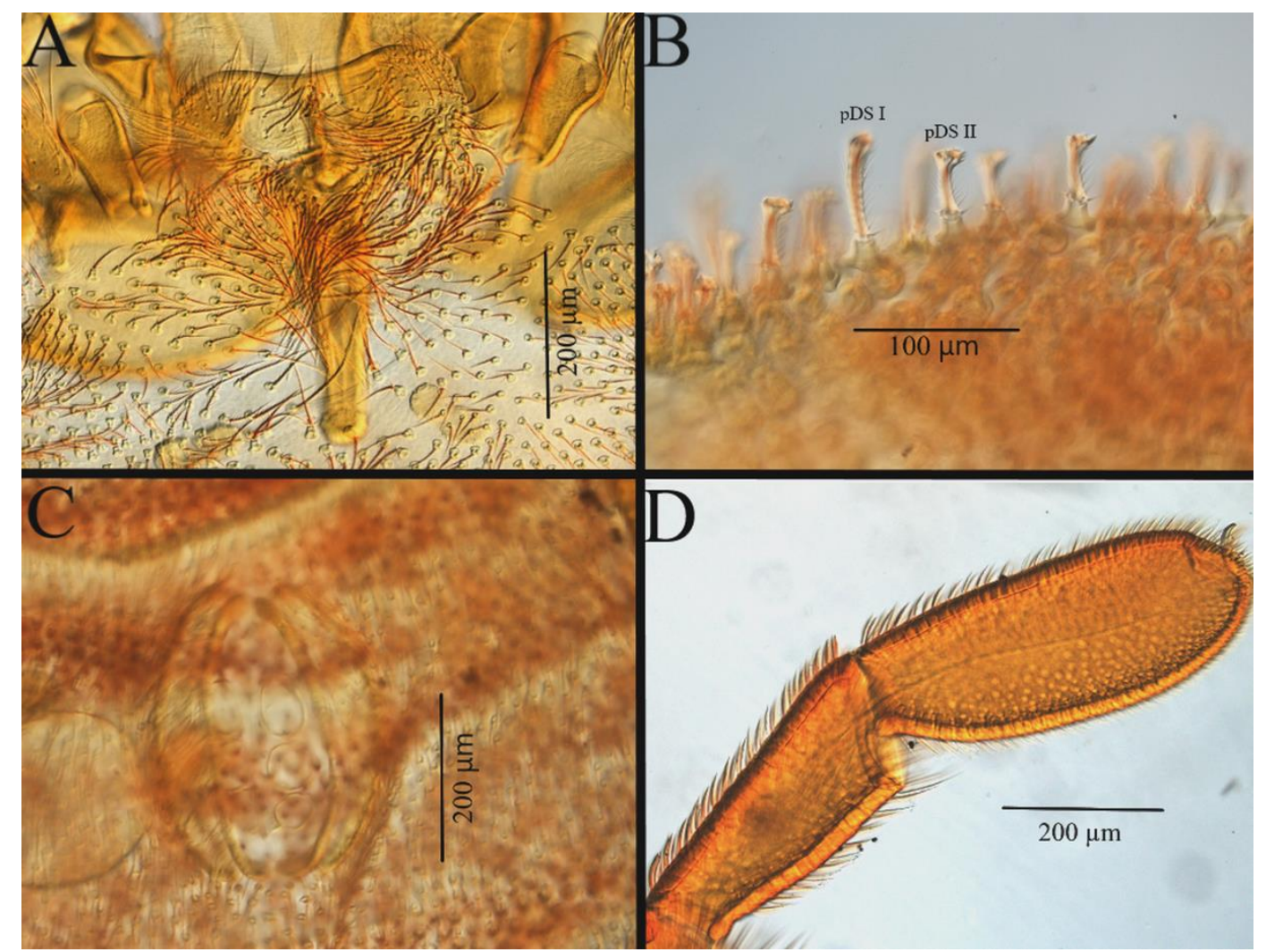

Figure 1. Trombidium rimosum Koch, (female), A. Crista metopica region B. $p D S$ I and $p D S$ II C. Genital opening D. Tibia and tarsus I.

Diagnosis: Larvae. Setae $\quad b s$ (hypostomalae) relatively long $(20-30)$ in the shape of simple, narrowing apically with distinct setules. Scutum longitudinally striate up to in ca. 1/5 length, anteriorly and whole remaining part punctuate. $S L$ setae placed on ca. 1/3 - 1/4 length of scutellum, anteriorly. $f \mathrm{D}$ formula: (2)4-6-44-2. All tarsi terminated two claws and a slender claw-like empodium. Anterior claw of tarsus III reduced.

Description: Larvae. Standard measurements in Table 1. All larvae reared from eggs laid by the females under laboratory conditions. Colours of living forms are red.

Idiosoma. Scutum longitudinally striate up to in ca. 1/5 length, anteriorly and whole remaining part punctate. $A M$ setae with a few barbs, $A L$ and $P L$ setae barbed. $P L$ longer than $A L$. Sensillae $(S)$ with a few minute barbs. Two pairs of eyes that include double lens, situated at level between scutum and scutellum. Anterior lens larger than posterior one. Scutellum bears one pair of barbed setae $c_{1}$ that they placed on ca. 1/3 - 1/4 length of scutellum, anteriorly. All dorsal setae situated on small plates, barbed and arranged in five rows. fD formula: (2)4-6-4-4-2 $\left(c_{1}-c_{3}, d_{l^{-}-3}\right.$, $\left.e_{1-2}, f_{1-2}, h_{1}\right)$ ( $h_{1}$ setae longer than others) (Figure 2). Claparéde's organs situated between coxae I and coxae II. $f \mathrm{Cx}$ formula: BB-BB-B. la setae with a few minute barbs and other coxal setae clearly setules. One pair of barbed intercoxal setae $3 a$ placed between coxal plates III. Posteriorly following four barbed setae situated on plates anterior and lateral to anal opening. Ventral setae barbed and arranged in three rows. $f \mathrm{~V}$ formula: $4 \mathrm{u}-2-2$ 
First Description of Larva of Trombidium rimosum C. L. Koch, 1837 (Acari: Trombidiidae) From Turkey

Table 1. Comparison of morphometric data of larvae of Trombidium rimosum Koch, 1837 and Trombidium brevimanum (Berlese, 1910) $(\mathrm{n}=15)$.

\begin{tabular}{|c|c|c|}
\hline Character & T. rimosum (Min- Max) & $\begin{array}{c}\text { T. brevimanum (Min- Max) } \\
\text { (Mąkol, 2005) }\end{array}$ \\
\hline $\mathrm{L}$ & $260-340$ & $264.6-347.6$ \\
\hline $\mathrm{W}$ & $165-205$ & $154.0-185.6$ \\
\hline $\mathrm{L} / \mathrm{W}$ & $1.38-1.78$ & $1.7-2.0$ \\
\hline$\overline{\mathrm{AA}}$ & $57-63$ & $51.5-59.4$ \\
\hline AW & $91-101$ & $99.0-104.9$ \\
\hline PW & $89-105$ & $97.0-106.9$ \\
\hline SB & $70-75$ & $65.3-83.2$ \\
\hline ASB & $80-82$ & $77.2-87.1$ \\
\hline PSB & $35-41$ & $35.6-43.6$ \\
\hline SD & $117-120$ & $114.8-124.7$ \\
\hline AP & $17-23$ & $27.7-33.7$ \\
\hline AM & $41-49$ & $39.6-47.5$ \\
\hline $\mathrm{AL}$ & $33-44$ & $43.6-53.5$ \\
\hline PL & $58-65$ & $61.4-75.2$ \\
\hline$S$ & $78-89$ & $71.3-87.1$ \\
\hline MA & $48-52$ & $43.6-53.5$ \\
\hline HS & $55-60$ & $45.0-56.0$ \\
\hline LSS & $132-145$ & $116.0-130.0$ \\
\hline SL & $62-70$ & $50.0-60.0$ \\
\hline DS_MIN & $26-32$ & $28.0-42.0$ \\
\hline DS_MAX & $48-60$ & $50.0-63.0$ \\
\hline Cx_I & $50-65$ & $49.0-58.0$ \\
\hline Tr_I & $30-35$ & $33.0-40.0$ \\
\hline $\mathrm{Fe} \_\mathrm{I}$ & $38-42$ & $38.0-47.0$ \\
\hline$\overline{\mathrm{Ge} \_I}$ & $23-25$ & $22.0-29.0$ \\
\hline
\end{tabular}




\begin{tabular}{|c|c|c|}
\hline Ti_I & $30-35$ & $33.0-40.0$ \\
\hline Ta_I & $56-59$ & $56.0-70.0$ \\
\hline LEG I & $239-254$ & $248.0-272.0$ \\
\hline Cx_II & $52-60$ & $44.0-60.0$ \\
\hline Tr_II & $35-40$ & $32.0-40.0$ \\
\hline Fe_II & $35-40$ & $35.0-44.0$ \\
\hline$\overline{\text { Ge_II }}$ & $20-23$ & $18.0-26.0$ \\
\hline Ti_II & $30-35$ & $32.0-37.0$ \\
\hline Ta_II & $50-53$ & $54.0-65.0$ \\
\hline LEG II & $218-237$ & $234.0-255.0$ \\
\hline Cx_III & $50-57$ & $44.0-53.0$ \\
\hline Tr_III & $35-40$ & $36.0-41.0$ \\
\hline $\mathrm{Fe} \_$III & $40-41$ & $37.0-46.0$ \\
\hline Ge_III & $20-21$ & $18.0-25.0$ \\
\hline Ti_III & $30-35$ & $35.0-44.0$ \\
\hline Ta_III & $45-48$ & $48.0-59.0$ \\
\hline LEG III & $205-228$ & $232.0-255.0$ \\
\hline IP & $682-746$ & $726.0-778.0$ \\
\hline
\end{tabular}

(last pair setae $=h_{2}$ longer than others). Ventral setae slightly thinner than dorsal setae. Anal opening without sclerite (Figure 3).

Gnathosoma. Setae $b s$ in the shape of relatively long and simple, narrowing apically with setules (Figure 4). Cheliceral blades with a small tooth. Adoral setae (or) short and smooth. Palpal femur with one small spine-like seta. Palpal tibia with three setae: one long with minute barbs, one nude, one short and nude. Palpal tibial claw bifid. Palpal tarsus with one solenidion, two eupathidia, four setae with barbed (Figure 5). $f \mathrm{Pp}$ formula:0-N-0BNN-4B $\zeta \zeta \omega$.

Legs. (Figures $6 \mathrm{~A}-\mathrm{F}$ ) Legs setal formula: [I] $\operatorname{Tr}(1 \mathrm{~B})-\mathrm{Fe}(5 \mathrm{~B}, 1 \mathrm{~N})-\mathrm{Ge}(4 \mathrm{~B}, 2 \sigma, 1 \kappa)$ - Ti $(5 \mathrm{~B}, 2 \varphi, 1 \kappa)-\mathrm{Ta}(16-17 \mathrm{~B}, 2 \zeta, 1 \omega$, $1 \varepsilon)$; [II] $\operatorname{Tr}(1 \mathrm{~B})-\mathrm{Fe}(4 \mathrm{~B})-\mathrm{Ge}(3 \mathrm{~B}, 1 \sigma)-$ 


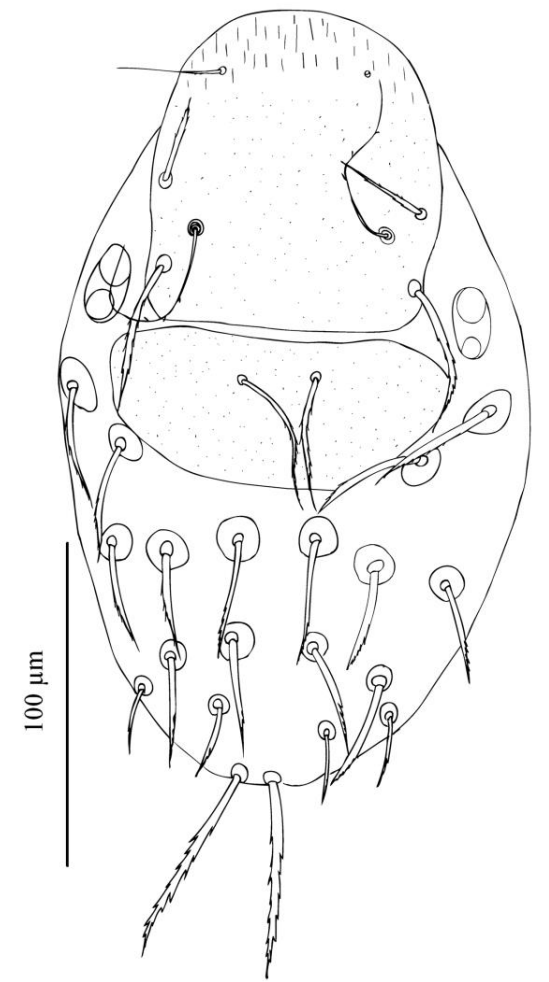

Figure 2. Trombidium rimosum Koch, (larvae), I Idiosoma, dorsal view

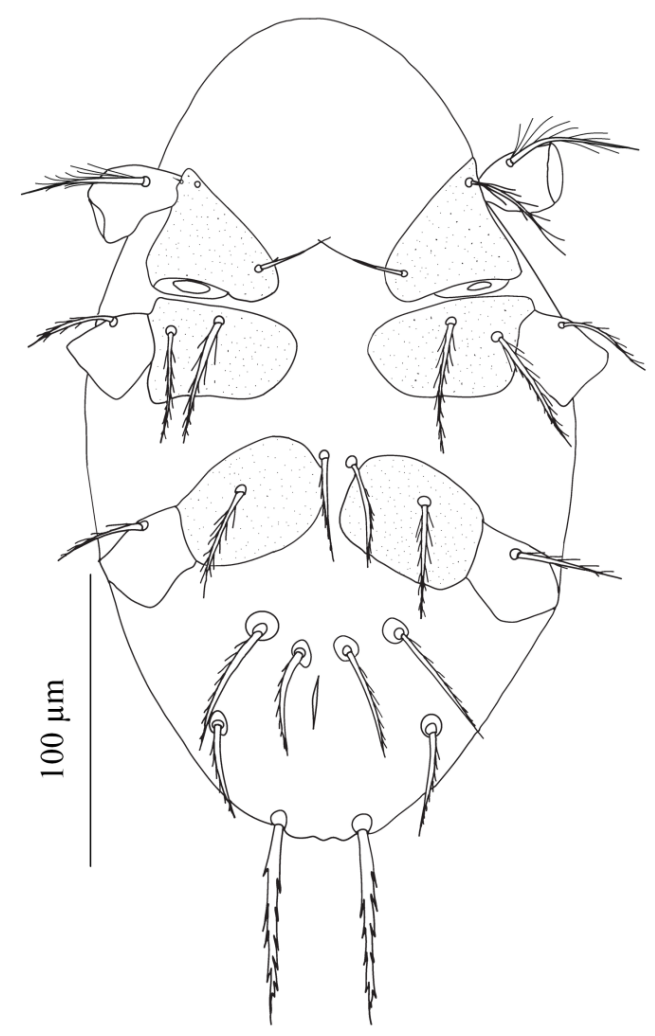

Figure 3. Trombidium rimosum Koch (larvae), Idiosoma, ventral view
Ti $(5 \mathrm{~B}, 2 \varphi)-\mathrm{Ta}(13 \mathrm{~B}, 1 \omega, 1 \varepsilon)$; [III] $\mathrm{Tr}$ $(1 \mathrm{~B})-\mathrm{Fe}(3 \mathrm{~B}, 1 \mathrm{~N})-\mathrm{Ge}(2 \mathrm{~B}, 1 \sigma)-\mathrm{Ti}(5 \mathrm{~B})$ $-\mathrm{Ta}(13 \mathrm{~B})$.

All tarsus terminated two claws and a slender claw-like empodium. Anterior claw of tarsus III reduced. Two accessory setae (one long and the other short) on Ta III terminated.

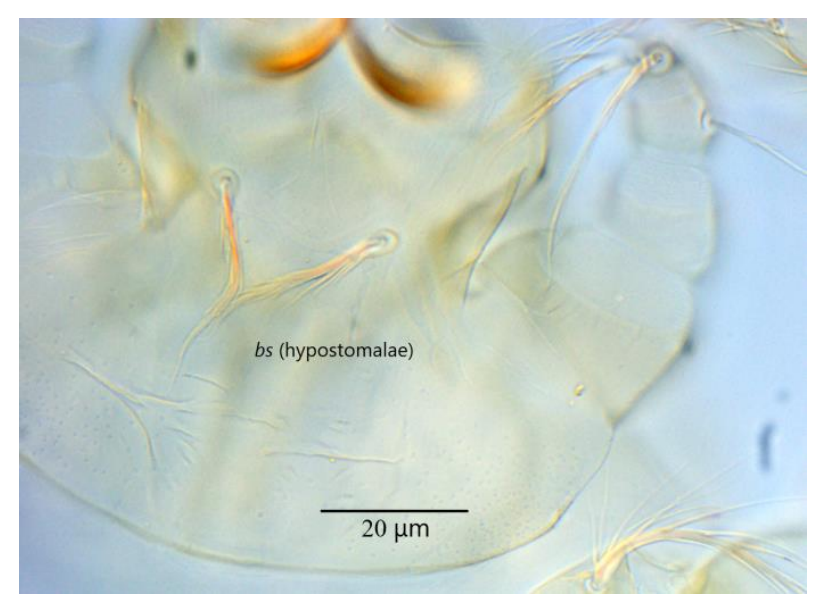

Figure 4. Trombidium rimosum Koch, (larvae), bs setae.

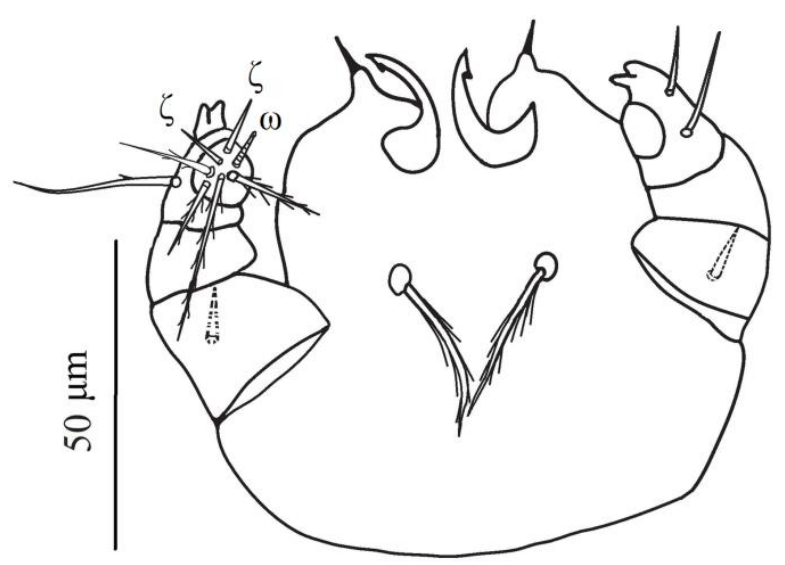

Figure 5. Trombidium rimosum Koch, (larvae), Gnathosoma

Distribution: Austria, Bosnia and Herzegovina, Czech Republic, France, Germany, Hungary, Italy, Poland (Mąkol and Wohltmann, 2012). 

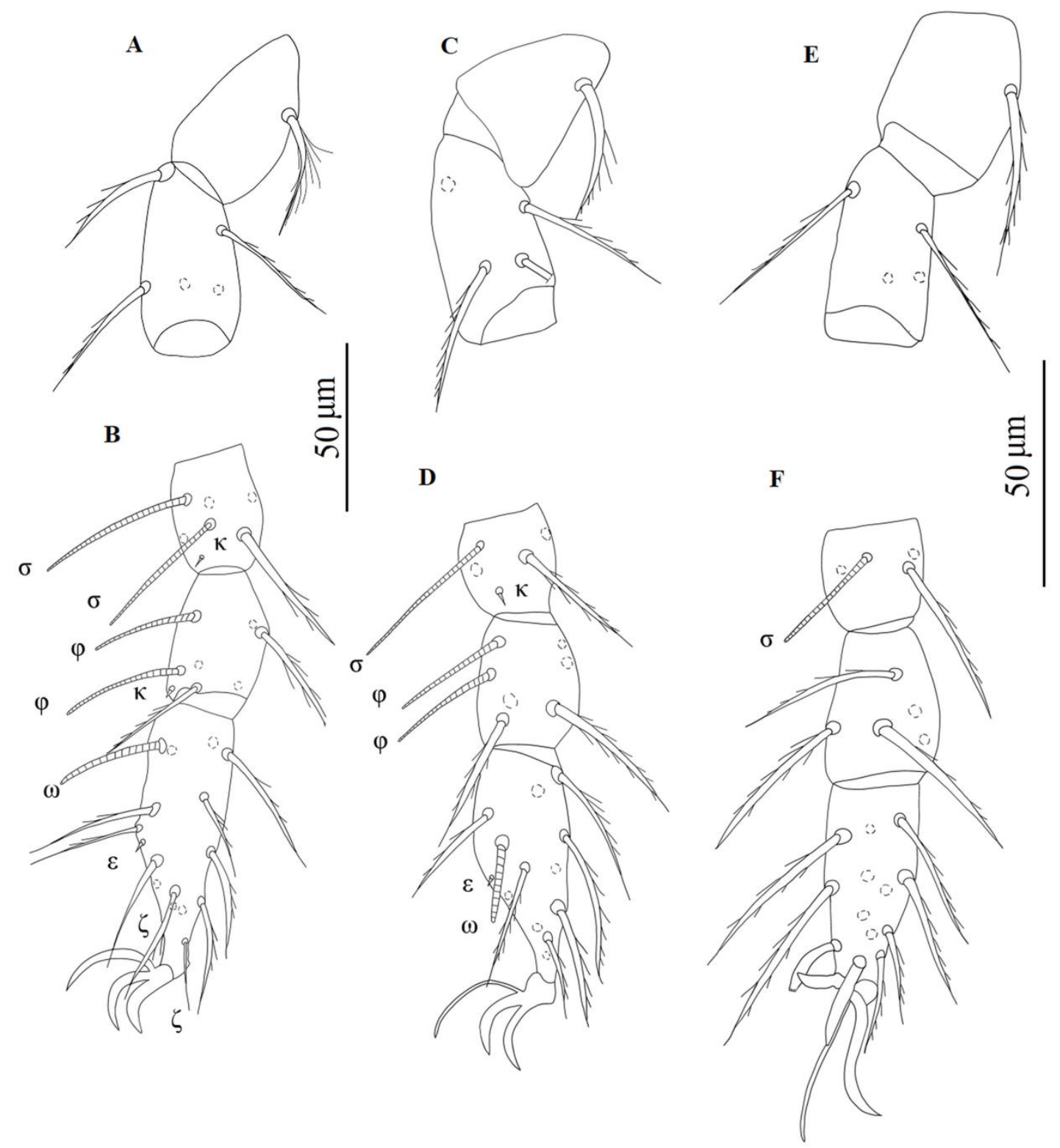

Figure 6. Trombidium rimosum Koch, (larvae), A. Leg I (trochanter - femur) B. Leg I (genu - tarsus) C. Leg II (trochanter - femur) D. Leg II (genu - tarsus) E. Leg III (trochanter - femur) F. Leg III (genu - tarsus).

\section{Discussion:}

Among both larvae and adults of the species belonging to the genus of Trombidium; $T$. rimosum closely similar to Trombidium brevimanum (Berlese, 1910). End of $p D S$ I more asymmetrical (hammerlike) in shape in adults $T$. rimosum while they slightly asymmetrical in $T$. brevimanum. Whole stem of $p D S$ I of adults of $T$. rimosum almost parallelsided but they gradually widening towards the top in T. brevimanum (Mąkol, 2005). Idiosoma densely covered with purple setae in adults of T. brevimanum (Mąkol, 2005) but in $T$. rimosum purple setae absent on idisoma.

The shape of the $b s$ setae are important in determining larval species of Trombidium. 
The larvae of $T$. rimosum differ from other larvae of Trombidium by the shape of the $b s$ setae. The $b s$ setae long $(20-30)$ and with distinct $8-10$ setules. With respect to larvae of $T$. rimosum closely similar larvae of $T$. brevimanum. However, bs setae of $T$. rimosum longer than of $T$. brevimanum. The length of $b s$ setae of $T$. brevimanum not stated but according to Figure 11 in Mąkol (2005) ca. 10 (op. cit., p. 56). Also, $b s$ setae of $T$. rimosum with $8-10$ setules but in T. brevimanum bs setae with $3-4$ setules (Mąkol, 2005). Moreover, $h_{l}$ setae placed on separate sclerite each one in $T$. rimosum but they placed on common sclerite in T. brevimanum (Mąkol, 2005). In terms of shape of the $b s$ setae, larvae of Trombidium rimosum also similar to Trombidium botovicum Haitlinger, 2004, Trombidium breei Southcoot 1986, Trombidium carpaticum (Feider , 1950),
Trombidium hungaricum Kobulej 1957 and Trombidium teres (André, 1928). Setae $c_{1}$ placed on ca. 1/3 - 1/4 length of scutellum, anteriorly in $T$. rimosum. But they situated at the anterior $1 / 2$ of scutellum in T. breei, T. hungaricum and T. teres (André, 1928; Southcott, 1986; Saboori et al., 2017). Number of ventral setae (excluding $h_{2}$ setae) 6 in $T$. rimosum while 4 setae in $T$. botovicum and 2 setae in T. carpaticum (Haitlinger, 2004; Saboori et al., 2017).

On the other hand, various morphological abnormalities have been observed in terrestrial parasitengona mites in a series of studies to date (e.g. Mąkol and Łaydanowicz, 2006). In one of the 15 larval slides examined, we observed $3 A L$ setae (instead of 2) on the scutum (Figure 7).

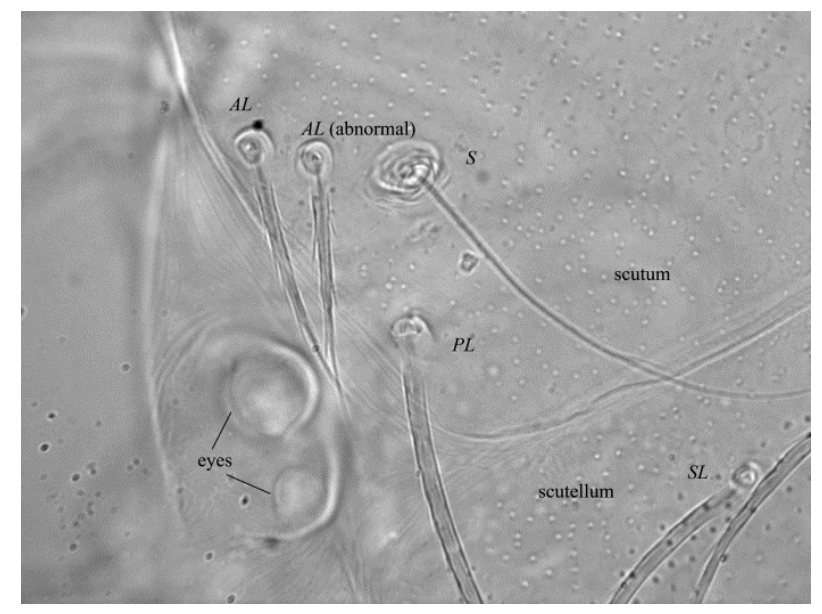

Figure 7. Trombidium rimosum Koch, (larvae), abnormal number of $A L$ setae.

\section{Acknowledgements:}

This work was mainly funded by Scientific Research Project (BAP) number FEN - A - 140613 - 0026 (Scientific Research Department of Erzincan University).

\section{References}

André, M. 1928. "Une nouvelle forme larvaire de thrombidion: Parathrombium teres n. sp.", Bulletin de la Societe zoologique de France, 53(1), 514 - 519. 
Haitlinger, R. 2004. "New records of mites (Acari: Prostigmata: Erythraeidae, Trombidiidae, Eutrombidiidae) from Croatia, with descriptions of three new species", Natura Croatica, 13(2), 143 160.

Mąkol, J. 2005. "Trombidiidae (Acari: Actinotrichida: Trombidioidea) of Poland. Fauna Poloniae", Museum and Institute of Zoology, Polish Academy of Sciences \& Natura Optima Dux Foundation, Warsaw, Vol. 1 [NS], $1-259$.

Mąkol, J. and Łaydanowicz, J. 2006. "Morphological abnormalities in terrestrial Parasitengona mites [Acari: Actinotrichida: Parasitengona]", Biological Letters, 43(2), $131-143$.

Mąkol, J. and Wohltmann, A. 2012. "An annotated checklist of terrestrial Parasitengona (Actinotrichida: Prostigmata) of the world, excluding Trombiculidae and Walchiidae", Annales Zoologici, 62(3), 359 - 562.

Mąkol, J. and Wohltmann, A. 2013. "Corrections and additions to the checklist of terrestrial Parasitengona (Actinotrichida: Prostigmata) of the world, excluding Trombiculidae and Walchiidae", Annales Zoologici, 63(1), 15 - 27.

Saboori, A., Šundić, M. and Pešić, V. 2017. "A new species of the genus Trombidium Fabricius (Acari: Trombidiidae), with a checklist of terrestrial parasitengone mites of Montenegro", Systematic and Applied Acarology, 22(4), 584-601.

Sevsay, S. 2017. "A checklist of the Erythraeoidea and Trombidioidea (Actinotrichida: Prostigmata) of Turkey",
Turkish Bulletin of Entomology, 7 (2): 175 $-196$.

Sevsay, S., Buğa, E. and Elverici, M. A. 2020. "New Species Of The Genus Trombidium (Acari: Trombidioidea) Parasitic On Spider From Turkey", Acarological Studies, 2(1), 34 40.

Sevsay, S., Adil, S., Karakurt, İ., Buğa, E. and Akman, E. 2016. "Five new records of the genus Trombidium (Actinotrichida: Trombidiidae) from northeastern Turkey", Turkish Journal of Zoology, 40(2), 151 - 156.

Southcott, R. V. 1986. "Studies on the taxonomy and biology of the subfamily Trombidiinae (Acarina: Trombidiidae) with a critical revision of the genera", Australian Journal of Zoology Supplementary Series, 34(123), 1 - 116.

Walter, D.E. and Krantz, G.W. 2009. "In: Krantz G.W. and Walter, D.E. (Eds.), Collecting, rearing, and preparing specimens", A Manual of Acarology. 3rd Edition, Texas Tech University Press, Texas, pp. $83-96$. 